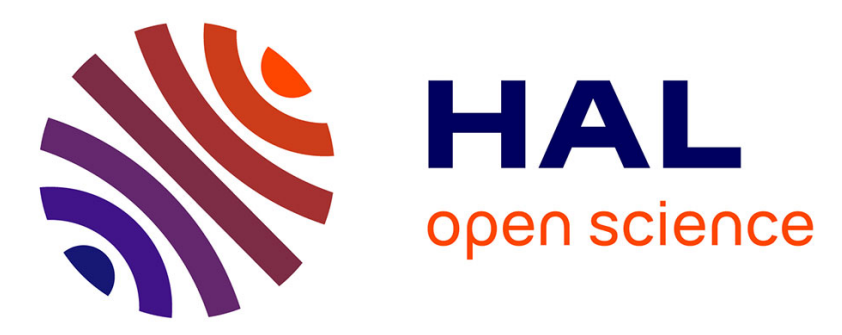

\title{
Effects of age, season and genetics on semen and sperm production in Apis mellifera drones
}

John Rhodes, Steven Harden, Robert Spooner-Hart, Denis Anderson, Gretchen Wheen

\section{- To cite this version:}

John Rhodes, Steven Harden, Robert Spooner-Hart, Denis Anderson, Gretchen Wheen. Effects of age, season and genetics on semen and sperm production in Apis mellifera drones. Apidologie, 2011, 42 (1), pp.29-38. 10.1051/apido/2010026 . hal-01003557

\section{HAL Id: hal-01003557 \\ https://hal.science/hal-01003557}

Submitted on 1 Jan 2011

HAL is a multi-disciplinary open access archive for the deposit and dissemination of scientific research documents, whether they are published or not. The documents may come from teaching and research institutions in France or abroad, or from public or private research centers.
L'archive ouverte pluridisciplinaire HAL, est destinée au dépôt et à la diffusion de documents scientifiques de niveau recherche, publiés ou non, émanant des établissements d'enseignement et de recherche français ou étrangers, des laboratoires publics ou privés. 


\title{
Effects of age, season and genetics on semen and sperm production in Apis mellifera drones*
}

\author{
John W. RHODES ${ }^{1}$, Steven HARDEN ${ }^{1}$, Robert SPOONER-HART ${ }^{2}$, \\ Denis L. ANDERSON ${ }^{3}$, Gretchen WHEEN ${ }^{4}$ \\ ${ }^{1}$ NSW Department of Primary Industries (DPI), Tamworth Agricultural Institute, 4 Marsden Park Road, Calala, \\ NSW 2340, Australia \\ ${ }^{2}$ University of Western Sydney, Centre for Plant and Food Science, Hawkesbury Campus, Locked Bag 1797, \\ Penrith South DC, NSW 1797, Australia \\ ${ }^{3}$ CSIRO Entomology, PO Box 1700, Canberra, ACT 2601, Australia \\ ${ }^{4}$ PO Box 223, Richmond, NSW 2753, Australia
}

Received 6 October 2009 - Revised 11 January 2010 - Accepted 20 January 2010

\begin{abstract}
Adult drone honey bees from 4 Australian breeding lines were reared under similar conditions and examined for semen and sperm production when 14, 21 and 35 days old, during spring, summer and autumn. Almost half (40.5\%) of all drones examined did not release any semen when manually everted. For those that released semen, the average volume released per drone was $1.09 \mu \mathrm{L}$ (range $0.72( \pm 0.04)-1.12$ $( \pm 0.04) \mu \mathrm{L})$ and the average number of sperms in the semen per drone was $3.63 \times 10^{6}$ (range $1.88( \pm 0.14)-$ $\left.4.11( \pm 0.17) \times 10^{6}\right)$. The release of semen was dependent on breeding line and age $(P<0.05)$, but not on the rearing season. The volume of semen released per drone was dependent on season, age, and breeding line $(P<0.05)$, while the concentration of sperm in the semen was dependent on season and breeding line $(P<0.05)$. Hence our data indicate that genetics underpins the maturation of drone honey bees as well as the volume of semen they release and the concentration of sperm in that semen.
\end{abstract}

Apis mellifera / drones / semen production / sperm

\section{INTRODUCTION}

Mating is the most significant function of an adult drone honey bee (Apis mellifera). During mating, semen is transferred from a drone into the genital orifice of a virgin queen on the wing, via the drone's endophallus, which is everted during copulation (Bishop, 1920a; Woyke, 1964). After mating, secretions and parts of the drone reproductive organs remain in the genital tract of the queen and signify a 'mating sign' (Woyke and Ruttner, 1958), which may function to prevent semen from

Corresponding author: D.L. Anderson, denis.anderson@csiro.au

* Manuscript editor: Klaus Hartfelder flowing out of the vagina (Bishop, 1920b). The semen consists of sperm, produced in the testes, and mucus, produced by large mucus glands. Sperm production is largely considered completed by the time drones reach sexual maturity, or when they are about 9-12 days old (Bishop, 1920a). Sperm is stored in the seminal vesicles of drones until they mate with virgin queens, at which stage it is ejaculated with mucus (semen) when the endophallus is everted. Normally, several drones will mate with a single virgin queen and copulations during flight follow one another about every two seconds (Koeniger et al., 1979). Each drone ejaculates from 6-12 million sperms and sperm from each mating accumulates in the queen's lateral oviducts (Woyke, 1960; 
Kerr et al., 1962). Most of this sperm is subsequently expelled from the queen (Page, 1986), but about 5-6 million migrate into the spermatheca, where they are stored until released in small quantities when the queen begins laying eggs (Zander, 1916; Bishop, 1920a, b; Page, 1986).

Previous studies in south east Australia found low numbers of sperm in the spermathecae of a high proportion of ovipositing commercially reared queen bees less than 35 days old (Rhodes and Somerville, 2003). This has serious implications for the productivity of colonies headed by such queens, as queen bees are generally superseded and killed by their colonies when they run out of sperm (Winston, 1987). Possible explanations could be that there were low numbers of drones of the right age available to mate with these queens, or sufficient numbers of drones of the right age but problems with their semen production, or a combination of both.

Limited data are available on the proportion of drones that release semen at the tip of the endophallus following manual eversion. Collins and Pettis (2001) reported 60\% of 12-day-old and Anderson (2004) 90\% of 20-day-old A. mellifera drones did not release semen after manual eversion. Several studies have been reported on the volume of semen produced by drones and the concentration of sperm in that semen. Woyke (1960; quoted in Rinderer, 1986) stated that an A. mellifera drone produces about $10 \times 10^{6}$ sperm, and $1 \mu \mathrm{L}$ of semen contains about $7.5 \times 10^{6}$ sperm. Koeniger et al. (2005) compared sperm numbers between $A$. dorsata and A. mellifera drones and provided a comparison of sperm counts from $A$. mellifera drones from various authors. Sperm counts ranged from a mean of $4(2 \pm 0.1) \times 10^{6}$ sperms per seminal vesicle for European A. mellifera (Rinderer et al., 1999), to $11.9 \pm 1.0 \times 10^{6}$ sperms per individual drone from an A. m. carnica colony (Schlüns et al., 2003). Collins and Pettis (2001) considered that the large variation reported in sperm numbers in semen might be due to using viscous and sticky semen to obtain counts. This may cause sperm cells to clump after being experimentally diluted, resulting in measurement errors. However, Bishop (1920a) reported that sperm release themselves more easily in the ejaculatory duct when mucus is more viscous. Koeniger et al. (2005) also stated that, in general, sperm numbers of individual drones show high variance and also suggested this could be due to errors in the sperm counting method. Nevertheless, they concluded that the cause of differences in sperm concentration reported from individual drones was yet to be determined.

The current study was carried out on A. mellifera drones in south east Australia, where studies had previously shown that commercially reared $A$. mellifera queens contained low concentrations of sperm in their spermathecae (Rhodes and Somerville, 2003). The aim was to determine whether particular characteristics of drones in that region might have been a contributing factor. We assessed the effects of age, genetics and season on semen and sperm production by examining 14, 21 and 35-day-old drones reared from four different breeding lines during spring, summer and autumn.

\section{MATERIALS AND METHODS}

\subsection{Obtaining drones and measuring semen and sperm production}

Three to five open-mated queen bees were produced by standard queen-rearing methods from each of four instrumentally inseminated breeder queen bees that were similar to A. mellifera ligustica and maintained by different commercial queenrearing operations. The daughter queens were used to provide drones for the current study and each represented dissimilar genetic backgrounds and identified as representing lines 1, 2, 3 and 4. Each of the daughter queens was marked and kept in a doublestory hive in a single apiary at Richmond, New South Wales, Australia. To reduce nutritional effects on the drone characteristics being examined, the hives were continuously replenished with pollen and sugar syrup throughout the study. All hives were also free of clinical signs of disease.

Drones were reared from each line during spring 2003 (Oct.-Nov.), summer 2004 (Feb.-Mar.) and autumn 2004 (April). Drone rearing and maintenance involved placing a queen bee in a queen excluder cage on a full frame of drone comb for $24 \mathrm{~h}$. 
After the queen had laid eggs in the comb, the comb was removed from the cage and placed in the middle of the brood combs in the brood chamber. Seventy-two hours before the drones were due to emerge the drone comb was placed back in the cage and the cage placed back in the brood chamber. Adult drones that emerged in the cage were marked with a coloured Posca ${ }^{\circledR}$ marking pen and released into the hive in which they were reared. All rearing and maintenance of adult drones was carried out in the hive headed by their respective queen mothers. Marked drones were confined to their hive, to prevent loss of drones, by a queen excluder placed between the brood chamber and bottom board and a second queen excluder placed on top of the brood chamber, beneath the super box.

Adult drones were examined at three ages, when 14, 21 and 35 days old. Within each age group, the oldest drones may have been up to $24 \mathrm{~h}$ older than the youngest drones, due to the time allowed for the queens to lay sufficient numbers of eggs in each comb. For each examination a sample of 30 drones, or the number of drones surviving to the age being sampled, was collected in the morning before drone flight commenced. Collected drones were held in cages, $16 \times 10 \times 3 \mathrm{~cm}$, with one side made of queen excluder and placed between frames of unsealed brood in a strong colony until required for laboratory analysis.

Drones were examined for the proportion that released semen at the tip of the endophallus after manual eversion and for the volumes of semen and numbers of sperm produced. Drones were everted manually following the methods described by Collins and Donoghue (1999). In brief, drones of a known age were stimulated to ejaculate by pressing on the thorax, which usually resulted in partial eversion of the endophallus. Further pressure on the abdomen forced the haemolymph into the endophallus and completed the process. Semen was collected from the tip of the endophallus, with particular care taken to avoid the collection of mucus, which may have caused semen to become viscous and sticky. Semen was collected using a Schley II apparatus and the semen volume, $\mu \mathrm{L}$, read directly from a Gilmont ${ }^{\circledR}$ micrometer syringe (model GS-1100) attached to the collection tip, to an accuracy of $0.1 \mu \mathrm{L}$. Drones that did not ejaculate semen or only a small amount of semen not sufficient for measurement were recorded as not releasing semen. The number of sperm in the semen was determined by placing $0.6 \mu \mathrm{L}$ of the semen (used to measure volume) in $1.5 \mathrm{~mL}$ water, mixing with a vortex, and counting the number of sperm present in 25 squares of an improved Neubauer haemocytometer, depth $0.1 \mathrm{~mm}$, $1 / 400 \mathrm{~mm}^{2}$ with the aid of a light microscope. The number of sperm produced by each drone was determined from the formula:

$$
\begin{aligned}
& \text { Number of sperm/drone }\left(\times 10^{6}\right)=\text { Volume } \\
& \text { of semen }(\mu \mathrm{L}) \times \text { total number } \\
& \text { of sperm counted in } 25 \text { squares } \\
& \text { of the haemocytometer } \times 25000 .
\end{aligned}
$$

\subsection{Statistical analysis}

Counts of drones with measurable amounts of semen are binomial variates. These were analysed using a logistic regression model, which is a generalised linear model with a logit link and binomial variance function. Season, age, line and all interactions were terms in the model and the significances of these terms were assessed by sequentially adding each term to the model and the changes in deviance between the nested models were compared to a Chi squared distribution with degrees of freedom being the degrees of freedom of the added term. Semen volume and number of sperm per drone for those drones with semen were analysed as a linear model with season, drone age, breeding line and all interactions included in the model. A square root transformation for both variables was necessary to meet the assumptions of normally distributed residuals. Predictions on the back-transformed scale were shown for all levels of the main effect terms (season, drone age and breeding line) and averaged over all other terms in the model. The logistic regression model was fitted using the statistical software R (R Development Core Team, 2007), utilising the general linear model (GLM) function and the linear model was fitted using ASReml (Gilmour et al., 2006). Significance of terms was assessed at a probability of 5 percent $(P \leq 0.05)$. Note that this study was conducted over a one-year period and hence any seasonal effects found may or may not be replicated again had the study been repeated in another year. Each season had only one replication and hence pseudo-replication is involved in any analysis with season as a factor.

\section{RESULTS}

\subsection{Semen release and semen volumes}

Only $59.4 \%$ of drones examined from the 4 breeding lines released measurable amounts 
Table I. The number of drones marked at emergence and the proportion of drones releasing a measurable amount of semen after manual eversion from the number examined for three seasons, for four breeding lines at three ages.

\begin{tabular}{|c|c|c|c|c|c|c|}
\hline \multirow{3}{*}{$\begin{array}{l}\text { Season } \\
2003-04\end{array}$} & \multirow[b]{3}{*}{ Line } & \multirow{3}{*}{$\begin{array}{l}\text { No. of } \\
\text { drones } \\
\text { marked } \\
*\end{array}$} & \multicolumn{3}{|c|}{$\begin{array}{l}\text { Number of drones releasing semen/ } \\
\text { number of drones examined }(\%)\end{array}$} & \multirow[b]{3}{*}{ TOTALS } \\
\hline & & & & Age (days) & & \\
\hline & & & 14 & 21 & 35 & \\
\hline \multirow[t]{4}{*}{ Spring } & 1 & 601 & $6 / 30(20.0)$ & $9 / 30(30.0)$ & $9 / 13(69.2)$ & $24 / 73(32.8)$ \\
\hline & 2 & 427 & $28 / 30(93.3)$ & $26 / 30(86.7)$ & $14 / 15(93.3)$ & 68/75 (90.6) \\
\hline & 3 & 190 & $20 / 30(66.7)$ & $6 / 30(20.0)$ & $4 / 6(66.7)$ & $30 / 66(45.4)$ \\
\hline & 4 & 284 & $15 / 30(50.0)$ & $19 / 30(63.3)$ & $21 / 29(72.4)$ & $55 / 89(61.7)$ \\
\hline \multirow[t]{4}{*}{ Summer } & 1 & 219 & $12 / 30(40.0)$ & $14 / 30(46.7)$ & $1 / 3(33.3)$ & $27 / 63(42.8)$ \\
\hline & 2 & 640 & $28 / 30(93.3)$ & $28 / 30(93.3)$ & $27 / 30(90.0)$ & $83 / 90(92.2)$ \\
\hline & 3 & 750 & $11 / 30(36.7)$ & $8 / 30(26.7)$ & $17 / 30(56.7)$ & $36 / 90(40.0)$ \\
\hline & 4 & 710 & $18 / 30(60.0)$ & $17 / 30(56.7)$ & $23 / 27(85.2)$ & $58 / 87(66.6)$ \\
\hline \multirow[t]{4}{*}{ Autumn } & 1 & 129 & $13 / 30(43.3)$ & $15 / 30(50.0)$ & na & $28 / 60$ (46.6) \\
\hline & 2 & 700 & $28 / 30(93.3)$ & 20/22 (90.9) & na & $48 / 52(92.3)$ \\
\hline & 3 & 460 & $9 / 30(30.0)$ & $9 / 30(30.0)$ & na & $18 / 60(30.0)$ \\
\hline & 4 & 820 & $23 / 30(76.7)$ & 6/13 (46.2) & na & $29 / 43(67.4)$ \\
\hline TOTALS & & 5,930 & $211 / 360(58.6)$ & $177 / 335(52.8)$ & $116 / 153(75.8)$ & $504 / 848(59.4)$ \\
\hline
\end{tabular}

na: No drones survived to provide data. $*$ Number of drones marked at emergence.

of semen at the endophallus after manual eversion (Tab. I). The percentage of drones that released semen was quite variable among the different genetic lines, with $91.7 \%$ from line 2 releasing semen, $40.3 \%$ from line $1,38.9 \%$ from line 3 and $64.8 \%$ from line 4 (Tab. II). The percentage of drones that released semen when aged 14, 21 and 35 days-old was $58.6 \%$, $52.8 \%$ and $75.8 \%$, respectively, while the percentage that released semen in spring, summer and autumn was $58.4 \%, 61.8 \%$ and $57.2 \%$, respectively (Tab. II).

Statistical analyses showed that semen release in the drones was dependent on their genetics (the breeding line they came from) and, to a lesser extent, on their age and the season in which they were produced. The deviance for each term and their associated degrees of freedom and $P$ values are shown in Table V.

For drones that released a semen sample after manual eversion, the mean semen volume was 1.09 (range 0.1-3.6) $\mu \mathrm{L}$ per drone, with a predicted mean of $1.03 \mu \mathrm{l}$ when adjusted for imbalance in drone numbers for age, season and breeding line. Predicted semen volumes and ranges of volumes for drones that
Table II. The proportion of drones releasing a measurable amount of semen after manual eversion from the total number examined for three seasons, three age groups and four breeding lines.

\begin{tabular}{lcc}
\hline Variable & $\begin{array}{c}\text { Proportion of } \\
\text { drones releasing } \\
\text { semen (\%) }\end{array}$ & Stat. Sig.* \\
\cline { 1 - 2 } Season & \multicolumn{2}{c}{ NS } \\
\hline Spring & $177 / 303(58.4)$ & \\
\cline { 1 - 2 } Summer & $204 / 330(61.8)$ & \\
\cline { 1 - 2 } Autumn & $123 / 215(57.2)$ & \\
\hline Age (days) & \multicolumn{2}{c}{$\mathrm{S}$} \\
14 & $211 / 360(58.6)$ & $\mathrm{b}$ \\
21 & $177 / 335(52.8)$ & $\mathrm{b}$ \\
35 & $116 / 153(75.8)$ & $\mathrm{a}$ \\
\hline Line & $79 / 196(40.3)$ & $\mathrm{C}$ \\
1 & $199 / 217(91.7)$ & $\mathrm{a}$ \\
2 & $84 / 216(38.9)$ & $\mathrm{c}$ \\
3 & $142 / 219(64.8)$ & $\mathrm{b}$ \\
\hline 4 & $504 / 848(59.4)$ & \\
\hline Overall mean & & \\
\hline
\end{tabular}

* Stat. Sig. = statistical significance. NS = not significant; $\mathrm{S}=$ significant. See text for detail. Means with letters in common are not significantly different, $P \leq 0.05$. 
Table III. Semen volume and range of volumes produced by drones for season, age and breeding line effects for drones that released a measurable (equal to or more than $0.1 \mu \mathrm{L}$ ) amount of semen after manual eversion.

\begin{tabular}{|c|c|c|c|c|}
\hline Variable & $N \sim$ & Semen volume/drone $\mu \mathrm{L}$ & & Stat. Sig. $^{+}$ \\
\hline & & Predicted mean \pm s.e. ${ }^{*}$ & Range & \\
\hline Season & & & & S \\
\hline Spring & 177 & $1.03 \pm 0.04$ & $0.2-3.6$ & $\mathrm{a}$ \\
\hline Summer & 204 & $0.92 \pm 0.05$ & $0.1-3.0$ & $a b$ \\
\hline Autumn & 123 & $0.82 \pm 0.04$ & $0.1-1.6$ & $\mathrm{~b}$ \\
\hline Total & 504 & & & \\
\hline Age(days) & & & & $\mathrm{S}$ \\
\hline 14 & 211 & $0.98 \pm 0.03$ & $0.1-2.2$ & $\mathrm{a}$ \\
\hline 21 & 177 & $1.07 \pm 0.04$ & $0.2-3.6$ & $\mathrm{a}$ \\
\hline 35 & 116 & $0.73 \pm 0.04$ & $0.2-3.0$ & $\mathrm{~b}$ \\
\hline Total & 504 & & & \\
\hline Line & & & & $\mathrm{S}$ \\
\hline 1 & 79 & $0.72 \pm 0.04$ & $0.2-1.8$ & $\mathrm{c}$ \\
\hline 2 & 199 & $1.12 \pm 0.04$ & $0.1-3.0$ & $\mathrm{a}$ \\
\hline 3 & 84 & $0.85 \pm 0.05$ & $0.1-2.6$ & $\mathrm{~b}$ \\
\hline 4 & 142 & $1.01 \pm 0.04$ & $0.2-3.6$ & $\mathrm{a}$ \\
\hline Total & 504 & & & \\
\hline Overall Mean & & $1.03 \pm 0.02$ & & \\
\hline
\end{tabular}

+ Stat. Sig. = statistical significance. $\mathrm{S}=$ significant. See text for detail. Means with letters in common are not significantly different, $P \leq 0.05$.

released a measurable volume of semen are shown in Table III for season, age and breeding line. Semen volumes were significantly higher for spring than summer and autumn reared drones, which produced the smallest volumes. Volumes were also significantly higher in the 14- and 21-day-old drones than in 35-day-old drones. A significant line effect was also identified, with lines 2 and 4 producing greater volumes than line 3 , with line 1 producing the smallest volumes. Significance for all terms in the model are shown in Table $\mathrm{V}$. The relative sizes of the $F$ values and a perusal of the predicted values showed that genetics (breeding line) had the largest effect on semen volume, followed by the age of drones with all other terms having much smaller effects.

\subsection{Sperm numbers}

The mean number of sperm produced per drone was $3.63($ range $0-19.1) \times 10^{6}$, with a predicted mean of $3.17 \times 10^{6}$ when adjusted for imbalance in drone numbers for age, season and breeding line. Predicted means of the number of sperm produced per drone and range of sperm numbers for drones releasing a measurable volume of semen are shown in Table IV for season, age, and breeding line. A season effect was identified, with autumn reared drones producing significantly more sperm than summer and spring reared drones, which produced the least sperm. An age effect was also identified, with 21-day-old drones producing more sperm than 14- and 35-dayold drones. Genetics also affected sperm production $(P<0.05)$, with drones from line 2 producing more sperm than drones from lines 3 and 4 and line 1 , which produced the least sperm. Significance for all terms in the model are shown in Table $\mathrm{V}$. The relative sizes of the $F$ values and a perusal of the predicted values showed that the season in which drones were reared had the largest effect on sperm numbers, followed by breeding line (genetics) and, to a lesser extent, age. 
Table IV. Number of sperm/drone $\times 10^{6}$ for season, age and line effects for drones, which released a measurable (equal to or more than $0.1 \mu \mathrm{L}$ ) amount of semen after manual eversion.

\begin{tabular}{|c|c|c|c|c|}
\hline Variable & $N \sim$ & \multicolumn{2}{|c|}{ No. sperm/drone $10^{6}$} & Stat. Sig. $^{+}$ \\
\hline & & Predicted means \pm s.e. ${ }^{*}$ & Range & \\
\hline Season & & & & $\mathrm{S}$ \\
\hline Spring & 177 & $1.88 \pm 0.14$ & $0.12-9.43$ & $\mathrm{c}$ \\
\hline Summer & 204 & $3.12 \pm 0.21$ & $0.12-19.13$ & $\mathrm{~b}$ \\
\hline Autumn & 123 & $4.24 \pm 0.25$ & $0.04-11.86$ & $\mathrm{a}$ \\
\hline Total & 504 & & & \\
\hline Age (days) & & & & $\mathrm{S}$ \\
\hline 14 & 211 & $2.83 \pm 0.15$ & $0.12-11.52$ & $\mathrm{a}$ \\
\hline 21 & 177 & $3.36 \pm 0.18$ & $0.18-13.52$ & $\mathrm{~b}$ \\
\hline 35 & 116 & $2.83 \pm 0.21$ & $0.12-19.13$ & $\mathrm{a}$ \\
\hline Total & 504 & & & \\
\hline Line & & & & S \\
\hline 1 & 79 & $2.12 \pm 0.19$ & $0.13-7.78$ & $\mathrm{c}$ \\
\hline 2 & 199 & $4.11 \pm 0.17$ & $0.12-19.13$ & $\mathrm{a}$ \\
\hline 3 & 84 & $2.84 \pm 0.22$ & $0.04-7.16$ & $\mathrm{~b}$ \\
\hline 4 & 142 & $3.11 \pm 0.17$ & $0.02-13.52$ & $\mathrm{~b}$ \\
\hline Total & 504 & & & \\
\hline Overall Mean & & $3.17 \pm 0.11$ & & \\
\hline
\end{tabular}

+ Stat. Sig. = statistical significance; $\mathrm{S}=$ significant. See text for detail. Means with letters in common are not significantly different, $P \leq 0.05$.

Table V. Significance of season, age, line and all interactions. Deviance statistics from logistic regression model for semen release and $F$ statistics from linear model for semen volume and sperm numbers together with their respective $P$ values.

\begin{tabular}{lc|cc|cc|cc}
\hline & & \multicolumn{2}{|c|}{ Semen release } & \multicolumn{2}{|c|}{ Semen volume } & \multicolumn{2}{|c}{ Sperm numbers } \\
\hline Term & DF & $\begin{array}{c}\text { Deviance } \\
\chi_{\mathrm{DF}}^{2}\end{array}$ & $\begin{array}{c}P \\
\text { value }\end{array}$ & $\begin{array}{c}F \\
\text { (ndf = DF, } \\
\text { ddf = 461) }\end{array}$ & $\begin{array}{c}P \\
\text { value }\end{array}$ & $\begin{array}{c}F \\
\text { (ndf = DF, } \\
\text { ddf = 460) }\end{array}$ & $\begin{array}{c}P \\
\text { value }\end{array}$ \\
\hline Season & 2 & 1.4 & 0.51 & 3.2 & 0.04 & 69.6 & $<.001$ \\
Age & 2 & 23.4 & $<.001$ & 11.7 & $<.001$ & 7.9 & $<.001$ \\
Line & 3 & 177.1 & $<.001$ & 12.5 & $<.001$ & 20.1 & $<.001$ \\
Season.Age & 3 & 0.7 & 0.88 & 2.3 & 0.08 & 3.1 & 0.03 \\
Season.Line & 6 & 8.3 & 0.22 & 2.2 & 0.051 & 3.3 & 0.004 \\
Age.Line & 6 & 10.2 & 0.12 & 3.0 & 0.01 & 1.3 & 0.27 \\
Season.Age.Line & 9 & 16.4 & 0.06 & 2.5 & 0.01 & 2.6 & 0.01 \\
\hline
\end{tabular}




\section{DISCUSSION}

The total numbers of drones that survived to ages 14, 21 and 35 days in each of our experiments are not known, but from the number of drones marked at emergence, it was clear that most did not survive longer than 35 days (Tab. I). Only about $4 \%$ of the 3821 marked spring- and summer-reared drones survived to 35 days, whereas none of the 2109 marked autumn-reared drones survived to 35 days (Tab. I). Hence, the life span of drones in our study was similar to that reported in other studies (Witherell, 1972; Fukuda and Ohtani, 1977).

The volumes of semen in drones of the four breeding lines (Tab. II) were also mostly comparable with those reported in other studies. The mean volume of semen per drone in our studies of $1.09 \mu \mathrm{L}$ (range $0.72 \pm 0.04-1.12 \pm$ $0.04 \mu \mathrm{L}$ ) (Tab. III) was within the range reported by Woyke (1960; quoted in Rinderer, 1986) of $1.3 \mu \mathrm{L}$ per drone, and by Collins and Pettis (2001) of 0.95 (range 0.48-1.67) $\mu \mathrm{L}$ per drone. However, the mean number of sperm produced per drone in our study, 3.63 (range $1.88( \pm 0.11)-4.11( \pm 0.17)) \times 10^{6}$ (Tab. IV) was at the lower end of sperm numbers reported in studies by Schlüns et al. (2003) of $11.9( \pm 1.0) \times 10^{6}$, Woyke $(1960$; quoted in Koeniger et al., 2005) of 11-12 $\times 10^{6}$, Collins and Pettis (2001) of $8.66 \times 10^{6}$, Köhler (1955; quoted in Ruttner, 1956) of $4.5 \times 10^{6}$ and Anderson (2004), $3.19( \pm 2.37) \times 10^{6}$. Interestingly, the sperm count obtained by Anderson (2004) was similar to that obtained here, was obtained using a similar counting method to ours, and was also obtained using drones in a commercial queen-rearing apiary in the same region as our study (south east Australia). Hence, while the volumes of semen produced by drones in our study were comparable with those from drones observed in other studies, the concentration of sperm in their semen was generally less. As the drone mother colonies in our studies were fed pollen and sugar syrup on a continuous basis, it is unlikely that the reduced sperm concentrations were due to nutritional effects. Perhaps the large differences in sperm numbers reported to date by different authors may be due to differences in the counting method used. In our study sperm was counted in semen released at the tip of the endophallus following manual eversion and dilution in water, whereas, in some other studies, sperm numbers have been determined in seminal vesicles.

In our study, increasing semen volume did not always correspond with increased sperm numbers. The predicted means for semen volume (Tab. III) showed a seasonal effect, with spring drones producing significantly higher volumes of semen than summer and autumn drones. Yet, autumn drones produced significantly more sperm than summer drones, which, in turn, produced more sperm than spring drones. The higher volume of semen produced by spring drones but lower numbers of sperm (Tab. IV) indicates a seasonal effect on sperm production.

The drones examined in our studies released semen at a much older age than has been previously reported. Earlier studies reported that sperm production in drones is largely completed by the time adult drones reach sexual maturity and can be released in the seminal fluids of drones at that stage, or when they are about 9-12 days old (Bishop, 1920a). Yet, in our study, a far higher proportion of drones released semen at the endophallus after manual eversion when aged 35 days $(75.8 \%)$ than when aged 14 days $(58.6 \%)$ or 21 days (52.6\%) (Tab. II). Anderson (2004) also reported that adult drones older than 20 days produced more semen than younger drones and, as mentioned, that study was carried out in a similar geographical region to that of the current study. Thus, there appears to be greater variation in the time that drones reach sexual maturity, which is the stage at which they release seminal fluid and sperm from the endophallus (Bishop, 1920a), than is currently recognized. Our results also indicated that semen release (and thus the time taken for drones to reach sexual maturity) is dependent on the genetics of the drones. For instance, significantly more drones from line 2 released semen at day 14 than drones of the other lines (Tab. I). Line 2 queen mothers were sourced from a honey bee breeding program which has been in operation in excess of 20 years with selection based on field evaluation combined with the 
use of instrumental insemination to produce the following season's breeding stock. While not specifically selecting drones producing a large volume of semen, these drones may have inadvertently been selected over drones producing a smaller volume of semen.

Sperm numbers in drone honey bees have been found to depend on body size (Schlüns et al., 2003). Even though we did not measure body size here, our results clearly showed that sperm numbers in drones also depend on the genetics of the drones. Drones from line 2 produced significantly more sperm after manual eversion than drones derived from the other 3 lines (Tab. IV). Indeed, our data indicates that the genetics of the drones underpins all aspects of seminal fluid and sperm production in drones, including the proportion of drones that release semen, the volume of semen produced per drone, and the number of sperms produced per drone.

A relatively large proportion $(40.6 \%)$ of all drones examined here when 14 to 35 days old did not release semen (and, hence, sperm). This was due to the drones either releasing no semen or insufficient amounts to be collected (Tab. I). High percentages of drones producing no or small amounts of semen after manual eversion were also reported by Collins and Pettis (2001) and Anderson (2004) for A. mellifera drones. Should queen bee mating involve one or more flights over one or more days mating with a sufficient number of drones until a sufficient, but unknown volume of semen containing an unknown number of sperm has transferred to the spermatheca, which then acts as the trigger for halting mating flights, then semen quality, semen volume and sperm numbers, of individual drones is reduced in importance. Data showing a high proportion of young, recently mated, ovipositing queen bees with low numbers of sperm in their spermathecae (Rhodes and Somerville, 2003) suggest the presence of a mechanism in the queen bee mating procedure which results in queen bees halting their mating flights and commence ovipositing irrespective of the number of sperm present in their spermatheca. Should such a mechanism be present, then the importance of sufficient numbers of drones of high quality at queen bee mating areas at the time of queen mating becomes greatly enhanced, from the perspective of the production of commercially reared queen bees. The issue of large numbers of apparently mature drones (drones aged 9-18 days) releasing little or no seminal fluid and sperm after manual eversion clearly warrants further investigation, particularly to determine if those drones are equally able to mate with queens as effectively as drones that produce large amounts of semen and sperm, and if queens that receive fewer sperms during mating store less sperm in their spermathecae than queens that receive more sperms during mating. This is because queen bees with fewer sperms in their spermathecae after mating tend to be superseded or replaced sooner by colonies than queens with higher numbers of sperms in their spermathecae.

Finally, our studies have shown that particular characteristics of adult drones in south east Australia, such as their slower maturation period and their production of relatively low numbers of sperms, may be contributing to a problem of low numbers of sperm in the spermathecae of commercially-produced queen bees in this particular region (Rhodes and Somerville, 2003). As those drone characteristics are also strongly influenced by genetics (see results), it would be advisable for queen breeders and producers in south east Australia (and, indeed, in all other regions) to routinely test drones of breeding lines for semen release and sperm production, ideally when drones are 14 days old.

\section{ACKNOWLEDGEMENTS}

The Honey Bee Program of the Rural Industries Research and Development Corporation, Canberra, Australia, funded this project. The NSW Department of Primary Industries, and the Centre for Plant and Food Sciences, University of Western Sydney provided staff and facilities. We would like to thank Mr. Michael Duncan, University of Western Sydney, for the provision of bees, apiary materials, and assistance with apiary management. We gratefully acknowledge the assistance of Ms Sharon Nielsen, Biometrician, NSW Department of Primary Industries, who assisted with the statistical analysis and provided comments on an earlier version of this paper. 
Effets de l'âge, de la saison et de la génétique sur la production de sperme et de spermatozoïdes chez les mâles d'Apis mellifera.

\section{Apis mellifera / mâle / production de sperme / variabilité}

Zusammenfassung - Die Auswirkungen von Alter, Jahreszeit und Genetik auf die Samenund Spermaproduktion von Apis mellifera Drohnen. Die vorliegende, in Südost-Australien durchgeführte Studie sollte überprüfen, ob und welche Rolle die in dieser Region vorkommenden Drohnen spielen könnten in der Frage der geringen Spermienzahlen, die in Spermatheken von Königinnen gefunden worden waren. Diese Befunde einer früheren Studie hatten gezeigt, dass kommerziell produzierte Königinnen in dieser Region nur geringe Spermienzahlen in ihren Spermatheken aufwiesen (Rhodes und Somerville, 2003).

Dazu untersuchten wir natürlich begattete Tochterköniginnen von künstlich besamten Apis mellifera ligustica-ähnlichen Mutterköniginnen, die wir von vier kommerziellen Züchtern erhalten hatten. Drohnen, die von Völkern dieser Mutterköniginnen im Frühjahr (Okt.-Nov. 2003), Sommer (Febr.-März 2004) und Herbst (April 2004) aufgezogen wurden waren, wurden im Alter von 14, 21 und 35 Tagen untersucht. Zur Gewinnung von Spermaproben wurden sie manuell evertiert. Als Parameter wurden der Anteil an Drohnen mit messbarem Samenvolumen $(0,1 \mu \mathrm{L}$ oder mehr auf dem evertierten Endophallus), das Volumen an produziertem Samen sowie die Spermienzahl pro Drohn bestimmt. Die Daten wurden anhand eines logistischen Regressionsmodells untersucht, das ein generalisiertes lineares Modell mit LogitVerknüpfung und binomialer Varianzfunktion darstellte.

Nur bei 59,4 \% der untersuchten Zuchtlinien konnten wir nach Eversion des Endophallus messbare Samenmengen finden. Die statistischen Analysen zeigten, dass vor allem die Genetik (d.h. die jeweilige Zuchtlinie) die produzierte Samemenge bestimmte. Das Alter war hingegen nur von geringer Bedeutung und die Jahreszeit spielte überhaupt keine Rolle.

Bei Drohnen, die ein messbares Samenvolumen freigesetzt hatten, betrug das mittlere Samenvolumen $1,0 \mu \mathrm{L}$, mit einem Minimum von $0,72 \pm$ 0,04 und einem Maximum von 1,12 $\pm 0,04 \mu \mathrm{L}$. Das Samenvolumen bei Frühjahrsdrohnen war signifikant größer $(P<0,05)$ als das von Sommeroder Herbstdrohnen, wobei letztere die gerinsten Volumina produzierten $(P<0,05)$. Bei den Spermienzahlen verhielten es sich jedoch genau umgekehrt, mit den höchsten Spermienzahlen bei Herbstdrohnen im Vergleich mit Frühjahrsoder Sommerdrohnen $(P<0,05)$. Die mittlere Spermienzahl pro Drohn lag bei 3,63 Millionen, mit einem Minimum von 1,88 $\pm 0,14$ und einem
Maximum von 4,11 $\pm 0,17 \times 10^{6}$, unabhängig von Alter, Zuchtlinie oder Jahreszeit. Diese Werte liegen damit am unteren Ende bereits publizierter Werte zu Spermienzahlen. 21 Tage alte Drohnen produzierten signifikant höhere Samenvolumina und Spermienzahlen als 14 und 45 Tage alte Drohnen $(P<0,05)$, während Drohnen bestimmter Zuchtlinien ein höheres Samenvolumen und mehr Spermien aufwiesen, was darauf hinweist, dass die Genetik eine wichtige Rolle hinsichtlich dieser Parameter spielt.

Die Daten zeigten außerdem eine breitere Variation hinsichtlich des Zeitpunkts der sexuellen Reife als früher berichtet, was von Bedeutung sein sollte für Züchter, wenn sie routinemässig Drohnen von Zuchtlinien hinsichtlich freigesetzter Samenmenge und Spermaproduktion untersuchen.

\section{Apis mellifera / Drohnen / Samenproduktion / Sperma}

\section{REFERENCES}

Anderson D.L. (2004) Improving queen bee production, Publication No. 04/153, Rural Industries Research and Development Corporation, Canberra, Australia, 16 p.

Bishop G.H. (1920a) Fertilization in the honeybee, I. The male sexual organs: their histological structure and physiological functioning, J. Exp. Zool. $31,225-265$.

Bishop G.H. (1920b) Fertilization in the honeybee, II. Disposal of the sexual fluids in the organs of the female, J. Exp. Zool. 31, 267-286.

Collins A.M., Donoghue A.M. (1999) Viability assessment of honey bee, Apis mellifera sperm using dual fluorescent staining, Theriogenology 51, 1513-1523.

Collins A.M., Pettis J.S. (2001) Effect of varroa infestation on semen quality, Am. Bee J. 141, 590-593.

Fukuda H., Ohtani T. (1977) Survival and life span of drone honeybees, Res. Pop. Ecol. 19, 51-68.

Gilmour A.R., Gogel B.J., Cullis B.R., Thompson R. (2006) ASReml User Guide Release 2.0. VSN International Ltd., Hemel Hempstead, UK.

Kerr W.E., Zucchi R., Nakakaira, J.T., Butolo J.E. (1962) Reproduction in social insects, J.N.Y. Entomol. Soc. 70, 265-270.

Koeniger G., Koeniger N., Fabritius M. (1979) Some detailed observations of mating in the honeybee, Bee World 60, 53-57.

Koeniger G., Koeniger N., Tingek S., Phiancharoen M. (2005) Variance in spermatozoa number among Apis dorsata drones and among Apis mellifera drones, Apidologie 36, 279-284.

Köhler F. (1955) Untersuchungen zum Problem der künstlichen Begattung der Bienenkönigin (Apis mellifica L.), Würzburg: Inaugral-Dissertation. 
Page R.E. (1986) Sperm utilization in social insects, Annu. Rev. Entomol. 31, 297-320.

R Development Core Team (2007) R: A language and environment for statistical computing. $\mathrm{R}$ Foundation for Statistical Computing, Vienna, Austria. ISBN 3-900051-07-0, URL: http://www. R-project.org.

Rhodes J., Somerville. D. (2003) Introduction and early performance of queen bees - some factors affecting success, Publication No. 03/049, Rural Industries Research and Development Corporation, Canberra, Australia.

Rinderer T.E. (1986) Bee genetics and breeding, Academic Press, Orlando, Florida, USA.

Rinderer T.E., Guzman L.I., Lancaster V.A., Delatte G.T., Stelzer J.A. (1999) Varroa in the mating yard. 1. The effects of Varroa jacobsoni and Apistan ${ }^{\circledR}$ on drone honey bees, Am. Bee J. 139, 134-139.

Ruttner F. (1956) The mating of the honeybee, Bee World 37, 3-15.
Schlüns H., Schlüns E.A., van Praagh J., Moritz R.F.A. (2003) Sperm numbers in drone honey bees (Apis mellifera) depend on body size, Apidologie 34, 577-584.

Winston M. (1987) The biology of the honeybee, Harvard University Press, Cambridge, Massachusetts, London, England, 281 p.

Witherell P.C (1972) Flight activity and natural mortality of normal and mutant drone honeybees, $\mathrm{J}$. Apic. Res. 11, 65-75.

Woyke J. (1960) Natural and artificial insemination of queen honey bees, Pszczel. Zesz. Nauk. 4 , 183-275.

Woyke J. (1964) Causes of repeated mating flights by queen honeybees, J. Apic. Res. 2, 17-24.

Woyke J., Ruttner F. (1958) An anatomical study of the mating process in the honeybee, Bee World 39, 3-18.

Zander E. (1916) Die Ausbildung des Geschlechtes bei der Honigbiene (Apis mellifera L.), Z. Angew. Entomol. 3, 1-20. 